Research Article

\title{
Ciguatera, an emerging human poisoning in Europe
}

\begin{abstract}
Ciguatera fish poisoning (CFP) is a food intoxication commonly affecting mainly the Caribbean Sea, Polynesia and other areas in the Pacific and Indian Oceans. Reports of CFP cases in several countries of Europe have most often resulted from Europeans travelling to CFP endemic areas. Recently however, dinoflagellates of genus Gambierdiscus, the producer of the toxins that cause CFP, have been detected in the Eastern Atlantic Ocean of the northern hemisphere and in the Mediterranean Sea. Actually, CFP cases have been confirmed in the Canary Islands and Madeira (Macaronesia area in the Eastern Atlantic). It is therefore very important to analyze the risks of ciguatera poisoning in Europe. With this, government of the Canary Islands decided to take preventive actions to prevent additional outbreaks of ciguatera in that area. With this work we establish the risk of consuming predatory fish, those most likely to have the toxin causing CFP, a total of 711 predatory fish samples were analyzed. Our work indicates that specific areas near Canary Islands, activity type, fish species and fish size determine the probability of catching fish containing ciguatoxin. Further, the possible contribution of climate change to the distribution of the toxin producers and ciguateric fish is discussed.
\end{abstract}

Keywords: Ciguatera fish poisoning, Gambierdiscus, Europe, Canary islands, Ciguatoxin
Volume 3 Issue I - 2015

\author{
F Acosta,' Jimena Bravo,' Francisco Cabrera \\ $\mathrm{Su},{ }^{2}$ Ana $S \mathrm{Ram}^{3}$ \\ 'Department of Animal Pathology, University of Las Palmas de \\ Gran Canaria, Spain \\ ${ }^{2}$ Vice Council of Fishing, Council of Agriculture, Ranching, Fishing \\ and Waters, Las Palmas de Gran Canaria, Spain \\ ${ }^{3}$ Department of Veterinary Epidemiology, University of Las \\ Palmas de Gran Canaria, Spain
} Correspondence: Department of Animal Pathology, University
of Las Palmas de Gran Canari, C/Trasmonta, Tel 0034928459740, Email facosta@dpat.ulpgc.es

Received: October 08, 2015 | Published: October 29, 2015
Abbreviations: CFP, Ciguatera Fish Poisoning; Ctxs, Ciguatoxins; FDA, Food \& Drug Administration; FAO, Food and Agriculture Organization; EFSA, European Food Safety Authority; FBS, Foetal Bovine Serum; OR, Odds Ratio; SST, Surface Seawater Temperature

\section{Introduction}

\section{Ciguatera poisoning}

Ciguatera fish poisoning (CFP) is the most common nonbacterial food intoxication in the world caused by ingestion of fish with bioaccumulated ciguatoxins (CTXs). ${ }^{1}$ The origin of CTXs is due to a biotransformation of other protoxins, gambiertoxins, which are produced by a microalga, a benthic dinoflagellate of the genus Gambierdiscus. These toxins are bioaccumulated in the food web when toxic dinoflagellates attached to surfaces, for example macroalgae, are consumed by herbivorous fish, which are then preyed on by carnivorous fish. ${ }^{1,2}$ The toxins undergo several oxidation steps during this passage through fish digestive systems, increasing their potency. ${ }^{3}$ These are in turn consumed by humans, which are at the end of the transmission chain and experience the full effects of

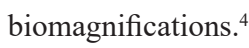

Top predators such as moray eel (Muraena spp.), grouper (Epinephelus spp.), snapper (Lutjanus spp.) and barracuda (Sphyraena spp.) have been suggested to be the high-risk species for CFP. ${ }^{2}$ Host fish are not distinguishable from edible ones because they are insensitive to the toxic effects of CTXs, as they appear to be free of symptoms, and they do not have special organoleptic characteristics. ${ }^{1}$ These biotoxins are lipophilic polycyclic ethers in nature, and therefore can be accumulated in fish muscle and viscera. CTXs are composed of 11-14 adjacent rings and are grouped in 3 subtypes, depending on their origin from the Pacific (P-CTX), the Indean Ocean (I-CTX) and the Caribbean (C-CTX). ${ }^{5}$ Two families of P-CTX with seven different structures have been described throughout the years, as well as two structures of C-CTX and four of I-CTX. ${ }^{6}$ In general, P-CTXs are considered the most potent, being 10-fold more potent than the Caribbean variants. ${ }^{7}$ The toxicity of the four described I-CTXs variants is estimated at about $60 \%$ of the P-CTXs. ${ }^{8}$

CTXs resist extreme temperature, weak acid treatments and alkaline conditions ${ }^{2,9}$ and not destroyed by any preserved methods. ${ }^{10}$ Mechanistically, the primary mode of action of the toxin is via binding to site 5 of the mammalian voltage-gated sodium channels in excitable tissues. CTXs inhibit $\mathrm{Na}+$ channel inactivation and shift their voltage dependence towards more negative potentials. Additionally they act as voltage-gated $\mathrm{K}+$ channel inhibitors. ${ }^{11}$ This slows down repolarization and keeps channels in an open, depolarized state that can ultimately lead to cell death. In humans, clinical manifestations of ciguatera appear $1-30 \mathrm{~h}$ after consumption of ciguatoxin. Poisoning is first manifested as gastrointestinal symptoms such as vomiting, diarrhoea, and abdominal pain, usually resolving naturally within a few days. Neurological symptoms develop 2-5 days later and can involve both peripheral and central features, commonly including paraesthesia and dysaesthesia.

The acute neurological symptoms usually resolve without specific treatment after 2-3 weeks, although relapses may occur. In some cases, the disease progresses with prolonged neurological symptoms including chronic fatigue, weakness and depression. A chronic phase of CFP lasting many years has also been reported in up to $20 \%$ of those acutely exposed ${ }^{1,6,12,13}$ but CFP sometimes causes death (case fatality rate, $0.1-20 \%$, depending on the area of impact). Sometimes, cardiovascular symptoms appear such as palpitations. Stress, excessive alcohol consumption, and ingestion of non-toxic fish may induce a recurrence of symptoms. ${ }^{13}$ Treatment of ciguatera is only symptomatic by the use of antiemetic, antidiarrheic, antihistaminic, analgesic and vitaminotherapy. Moreover, intravenous injection of mannitol early after the onset of the disease seems to be the most efficient therapy for CFP. ${ }^{1}$ Although rarely fatal, ciguatera poisoning is the most common seafood poisoning worldwide, affecting approximately 50,000500,000 people annually, but a lack of diagnostic methods for CFP likely results in underreporting of cases..$^{14,15}$ 


\section{Worldwide incidence of ciguatera}

World production of fish catch has continued to rise over the years to feed the growing population of coastal and islands areas, providing an alternative source of protein in Europe and America. This demand is a growing pressure on the fishing grounds, and in combination with the globalization of trade, is leading to increased imports and increased consumption of fish from areas where ciguatera is endemic. ${ }^{16}$ This disease is widespread in tropical and subtropical marine areas affecting mainly the Caribbean Sea, Polynesia and other areas in the Pacific and Indian Oceans. ${ }^{14}$ In subtropical areas, the presence of dinoflagellates is seasonal and likely affected by severe weather events. Worldwide, the Cook Islands in the Pacific appear as the area with the highest incidence and where the risk to contract ciguatera as $>25 \%{ }^{14}$

Recent observations also suggest the expansion of the biogeographical range of Gambierdiscus spp. and ciguatoxic fish, i.e., Cabo Verde and Canary Islands (Macaronesia, Eastern Atlantic Ocean waters), Cameroon, Greece (Mediterranean Sea) and Gulf of Mexico. ${ }^{6,17}$ In Asia they have also been located recently toxic microalgae, specifically off the coast of Korea. ${ }^{18}$ These poisoning outbreaks described reinforce the idea of the geographical spread of ciguatera endemic areas worldwide. ${ }^{17} \mathrm{CFP}$ outbreaks that occurs outside of endemic areasare often linked to consumption of imported toxic fish or in travelers returning from endemic CFP areas ${ }^{6,17}$ as recently there have been reports of ciguatera poisoning in New York, Germany ${ }^{11}$ and France. ${ }^{19}$

\section{Ciguatera in Europe}

The interest for CFP in Europe (e.g., France, Spain, the Netherlands, Germany and Italy) has been increasing during the last years because more and more CFP cases are appearing, usually in people consumed imported ciguateric fish or who travelled to CFP areas. From 1971 to 2007 have been reported data on cases of poisoning from eating rabbit fish (Siganus luridus), saupe (Sarpa salpa) and other edible fish (Siganusspp.) in the Eastern Mediterranean Sea. ${ }^{6}$ Thus, the European Union has adopted policies to ensure food safety, but global mobility and intensive tourism to tropical and subtropical areas has led to an increased risk of contracting pathologies that rarely occur in temperate latitudes. However, in recent years, not only is producing an increase in the incidence of ciguatera in endemic areas, but in subtropical areas the incidence is also being increased and is spreading the appearance of dinoflagellates to temperate climates, therefore, they are appearing with ciguatoxin fish near the coasts of Europe and in the Mediterranean Sea. ${ }^{20}$

\section{Ciguatera in macaronesia area}

Since 2004, recent epidemiological data reported some outbreaks of poisoning diagnosed as CFP from eating various fish species, especially in the Macaronesia area in the Eastern Atlantic, a temperate zone, considered a non-endemic region for CFP. In 2004, the first outbreak of CFP in the Canary Islands archipelago was documented: 5 individuals were intoxicated by a long fin yellow tail (Seriola rivoliana) of $26 \mathrm{Kg}$ captured by sport fishing along the East of Canary Islands. ${ }^{21}$ In the same year, Gambierdiscus spp. was found in the waters of these islands. ${ }^{22}$ In 2008, the second outbreak occurred in Tenerife (West Island of this archipelago) affecting to 25 individuals that bought an amberjack of $37 \mathrm{Kg}$ in a local market. In 2009, other outbreak was documented in the archipelago affecting to 9 individuals from Tenerife and Gran Canaria that consumed greater amberjack (Seriola dumerili) captured by sport fishing ${ }^{17,21}$ with confirmation of the presence of Caribbean CTX type I.
CFP outbreaks and the identification of CTXs were reported in Madeira Archipelago (Macaronesia, Eastern Atlantic Ocean) from 2007 to 2009 in various fish species (Seriola spp., Sparisoma credence, Serranus atricauda, Bodianus scrofa, Balistes capriscus and Pagrus pagrus)., ${ }^{6,23}$ In 2010, only an outbreak occurred in canarian area, affecting to 6 individuals in Tenerife. There occurs the same in 2011 in Gran Canaria with 5 individuals affected by consumption of sport fishing amberjack. In 2012 there are 22 cases of consumption poisoning amberjack in Lanzarote and Tenerife, of sport fishing and local market, respectively. ${ }^{25}$ In 2011 were described a new toxic dinoflagellated found in the Canary Islands coasts in 2004. This marine benthic dinoflagellate was appointed like Gambierdiscus excentricus..$^{14,20}$ and very recently, other novel toxic dinoflagellated was identified off the Canary Island coastal waters, Gambierdiscus silvae. $^{26}$

Following the first identification of CTXs in S. rivoliana in the Canary Islands, government of the Canary Islands decided to take preventive actions against a possible onset of ciguatera in that area. Those actions consisted on the screening of the presence of CTXlike compounds in fish specimens with a weight exceeding $15 \mathrm{~kg}$ and which were caught in the 34.1.2 division according to the FAO fishing area (Food and Agriculture Organization of the United Nations-FAO) (previously associated with CFP episodes). CTXs were screened by the PHA using the immunoassay Cigua-Check ${ }^{\circledR}$ test kit (Oceanit, Honolulu, HI, USA). However, this test was subject to considerable analytical controversy and unacceptable rates of false-positives and false-negatives, and its manufacture has now stopped. ${ }^{1}$ Therefore, appropriate analyzes have been conducted in the University Institute of Animal Health and Food Safety since 2011.

CFP is a major public health problem in the Pacific and Caribbean tropical areas where the pathology is known to most of the physicians and where the prevention is regularly performed to inform the population and particularly the fishermen about the risk of consumption some carnivorous fish. ${ }^{19}$ To reduce the potential hazard of CFP, for example, the U.S. Food and Drug Administration (FDA) recommend that primary processors obtain information about harvest location and species of fish to determine the risk of contamination. So, with the publication that made the European Food Safety Authority (EFSA), which published an article on emerging toxins in Europe, including ciguatoxin (European Food Safety Authority-EFSA), European legislation has to be modified to give an indication of the method of analysis CTXs reference and about the limits of safety regulations fishery products. Risk analysis approach is highly advisable to confront CFP in Macaronesia and establish recommendations. Risk analysis for ciguatera in Europe should be addressed by implementing efforts proportional to the present situation. ${ }^{6}$ Based on this, we have made univariate and multivariate analysis to determine the risk factors of catching a fish with ciguatoxin in our area.

\section{Materials and methods}

\section{Epidemiological study}

A serial cross-sectional survey of fish was undertaken between September 2011 and December 2014. The study was conducted with fish that were fished or captured in the Canary Islands area as is compulsory by the government, and that were sent to University of Las Palmas de Gran Canaria, Canary Islands) to analyze them. A total of 711 fish were analyzed. The fish samples belong to the species greater amberjack and long fin yellow tail species (Seriola dumerilli and Seriola rivoliana) $(\mathrm{n}=557)$, generically called amberjack; blue marlin (Makaira nigricans) $(\mathrm{n}=31)$, dusky grouper 
(Epinephelus marginatus) $(\mathrm{n}=85)$, wahoo (Acantocybium solandri) $(\mathrm{n}=32)$, bluefish (Pomatomus saltatrix) $(\mathrm{n}=2)$ and swordfish (Xiphias gladius) $(\mathrm{n}=4)$. For all samples, information about different variables was registered. These factors were the zone, activity type, fish species, cold or warm months depending on the temperature, the weight and the presence or not of ciguatoxin.

\section{Extraction and purification procedure of CTXs from fish samples}

Briefly, fish flesh were extracted and purified as follows, $10 \mathrm{~g}$ of fish flesh was cooked at $70^{\circ} \mathrm{C}$ for $10 \mathrm{~min}$ and mixed for $5 \mathrm{~min}$ in $30 \mathrm{ml}$ acetone (Ultraturrax, $17500 \mathrm{xg}$ ). Acetone soluble extract was recovered after 5 min centrifugation at $600 \mathrm{xg}$ at $4{ }^{\circ} \mathrm{C}$ and filtrated using $0.45 \mu \mathrm{m}$ nylon filters. The extraction with acetone was repeated twice and both acetone soluble extracts were pooled and dried on a rotary evaporator (Lewis, 2003). The dried extract was further purified using liquid/ liquid partition in order to eliminate excessive fatty acids that may interfere with the detection of CTXs. For that purpose, dried extract was dissolved in $5 \mathrm{ml}$ methanol: water (9:1) and partitioned twice with $5 \mathrm{ml}$-hexane $(1: 1, \mathrm{v} / \mathrm{v})$. The $\mathrm{n}$-hexane fractions were discarded and the methanol: water fraction was dried for further purification. The dried extract was dissolved in $5 \mathrm{ml}$ ethanol: water $(1: 3)$ and partitioned twice with $5 \mathrm{ml}$ diethyl ether $(1: 1, \mathrm{v} / \mathrm{v})$. The ethanol: water fraction was discarded and the diethyl ether fractions were pooled, dried and then dissolved in $4 \mathrm{ml}$ methanol and keep at $-20^{\circ} \mathrm{C}$ until analysis.

\section{Neuroblastoma (neuro-2a) cell maintenance and cytotoxicity assay}

Mouse Neuro-2a cells (ATCC, CCL-131) were routinely grown in RPMI 1640 medium supplemented with $10 \%$ foetal bovine serum (FBS) and $1 \mathrm{mM}$ sodium pyruvate at $37{ }^{\circ} \mathrm{C}$ in a $5 \% \mathrm{CO} 2$ humidified atmosphere. ${ }^{27}$ For experiments, cells were seeded in a 96-well microplate in 5\% FBS RPMI 1640 medium at an approximate density of 35,000 cells per well. Cells were incubated in the same conditions of temperature and atmosphere as described for cell maintenance. After $24 \mathrm{~h}$ incubation of the neuro-2a cells and just before exposure to fish extracts and CTX standard solution to test, one half part of the microplate received $0.1 \mathrm{mM}$ ouabain and $0.01 \mathrm{mM}$ veratridine allowing a reduction of $20 \%$ in cell viability. ${ }^{27}$ An equivalent amount of fish extract or P-CTX-1B standard solution to test is first evaporated until dryness under $\mathrm{N} 2$ flux at $40{ }^{\circ} \mathrm{C}$ to remove the methanol completely. Dried extracts are further dissolved in 5\% FBS RPMI 1640 medium, serially diluted in the same medium and $10 \mu 1$ of each concentration is directly added into the well of both halves of the microplate (with and without $\mathrm{O} / \mathrm{V}$ treatment) in order to compare cell response in the presence and absence of $\mathrm{O} / \mathrm{V}$ treatment. An equal volume in each well was corrected using phosphate buffer solution. All doses as well as all experiments were performed in triplicate. The sensitivity of the neuro-2a cells to the presence of CTX was calibrated each day of the experiment with a standard solution of P-CTX-1B at $20 \mathrm{ng} / \mathrm{ml}$. The CTX-like content in the samples tested was quantified after analysis of cell viability, as further described below.

\section{Cytotoxicity assay final}

After $24 \mathrm{~h}$ exposure of the neuro-2a cells to fish extracts and P-CTX-1B standard material, cell viability was used as an endpoint for cytotoxic effects measurement. Cell viability was assessed by incubating cells with a $5 \mathrm{mg} / \mathrm{ml} \mathrm{MTT}$ solution [3-(4,5-dimethylthiazol2-yl)-2,5-diphenyl tetrazolium bromide]. Absorbance values were read at $492 \mathrm{~nm}$ using an automated multi-well scanning spectrophotometer and results were further analyzed using the software Prism4. The viability of cells was expressed in relation to the viability of the corresponding cell control (with or without $\mathrm{O} / \mathrm{V}$ treatment) and the $50 \%$ of effects $(\mathrm{ICO} / \mathrm{V}+50)$ was calculated according to the doseresponse curve obtained using a sigmoid regression curve with a variable Hill slope.

\section{Statistical analysis}

The collected data were compiled and tables were produced using 2007 Microsoft Office Excel software (version 12.0.4518.1014) (Redmond, WA) and were check and corrected. In all analyses, individual fish were the analytical units. All statistical tests were performed with SPSS software version 18.0 for Windows (SPSS Inc., Chicago, USA). Descriptive statistics are presented. The presence of ciguatoxin in fish was used as the dependent variable. Independent dichotomous variables were analyzed with $2 \times 2$ contingency tables and for significance; the chi-squared test and Fisher's exact test were done. Continuous variables were categorized according to two groups and analyzed as categorical variables. The odds ratio (OR) and its $95 \%$ confidence interval was used to compare the odds of finding a fish contaminated with ciguatera toxin within some variables. And potential confounders were controlled by logistic regression. After univariable screening, variables showing an association with the outcome variable with a $p$ value of $<0.25$ were considered for inclusion in the multivariable model. ${ }^{28}$ Associations were considered statistically significant at a $p$ value $<0.05$. To assess the fit of the logistic regression model, the Hosmer-Lemeshow and Pearson chisquared statistic were determined.

\section{Results and discussion}

A total of 711 fish were analyzed. The summary of the samples received in our laboratory can be seen in Table 1. In the same table it is shown summarizes univariate analysis between the risk of having ciguatera among fish and several risk factors. Variables that showed statistical significance with the risk of having ciguatera were the areas, activity type, fish 2 species (values the whole amberjack and grouper off the other species) and amberjack weight. Variable without statistical significance was fish 1 species (values amberjack off the other species), although the P-value is close to be significant. No relationship was found between the warmer or colder months. Distributing the samples into two groups according in the area where they were caught in the Canary Islands, we find that we have received $46,3 \%(n=329)$ of samples from the Western (Tenerife, La Gomera, La Palma and El Hierro) and 53,6\% (n=381) of samples from the Eastern (Lanzarote, Fuerteventura and Gran Canaria). There are more samples with CTXs $(13,1 \%, \mathrm{n}=50)$ in the Eastern (Table 1).

With this distribution we have significant differences between the two zones $(p<0.05)$, being more than twice times more likely to be risk factor to catch a fish with ciguatoxin in the eastern islands. This could be explained because the Canary Islands are located in the transition zone between cold waters of African coastal upwelling and warmer ocean waters from the West, and together with the geographical distribution of the islands, aligned East-West, allows the existence of a strong thermal gradient of about $2{ }^{\circ} \mathrm{C}$ in surface seawater temperature (SST) from western warmer waters to eastern colder ones. Thus, tropical species are dominant to the western islands and temperate species to the eastern. ${ }^{29,30}$ But the rise in the SST has been linked with the weakening of the Cold Canary Current and the African upwelling, and is strongly affecting species distributions. Fish populations are suffering a tropicalization process, and many of the new species of algae and invertebrates reported from the archipelago are species with well-known tropical affinities. ${ }^{30}$ For this, in the western islands should not slow down the ciguatera control. 
Table I Distribution samples by area, activity type, fish species, months depending in the water temperature and weight

\begin{tabular}{|c|c|c|c|c|}
\hline Distribution samples & & $\begin{array}{l}\text { Total samples } \\
n=197\end{array}$ & $\begin{array}{l}\text { Ciguatera } \\
n=17\end{array}$ & No ciguatera $n=180$ \\
\hline \multirow{2}{*}{ Areas* } & Eastern & 85 (43\%) & 12 (I4\%) & 73 (86\%) \\
\hline & Western & II 2 (57\%) & $5(4 \%)$ & 107 (96\%) \\
\hline \multirow{2}{*}{ Activity type } & Sport & $8(4 \%)$ & $4(50 \%)$ & $4(50 \%)$ \\
\hline & Commercial & $189(96 \%)$ & $13(7 \%)$ & $176(93 \%)$ \\
\hline \multirow{2}{*}{ Fish Species** } & Amberjack & $182(92 \%)$ & $16(9 \%)$ & 166 (91\%) \\
\hline & Others & 15 (8\%) & I (7\%) & 14 (93\%) \\
\hline \multirow{3}{*}{ Months*** } & Warm & 88 (45\%) & $12(14 \%)$ & 76 (86\%) \\
\hline & Cold & 109 (55\%) & $5(5 \%)$ & $104(95 \%)$ \\
\hline & & $\begin{array}{l}\text { Total samples } \\
n=182\end{array}$ & $\begin{array}{l}\text { Ciguatera } \\
n=16\end{array}$ & No ciguatera $n=166$ \\
\hline \multirow{2}{*}{ Amberjack Weight } & $>38 \mathrm{~kg} * * * *$ & $29(16 \%)$ & $7(24 \%)$ & $22(76 \%)$ \\
\hline & $<38 \mathrm{~kg}$ & 153 (84\%) & $9(6 \%)$ & 144 (94\%) \\
\hline
\end{tabular}

* Areas: Eastern (Lanzarote, Fuerteventura and Gran Canaria),Western (Tenerife, La Gomera, La Palma, El Hierro)

** Fish species: Others (blue marlín, dusky grouper and wahoo)

*** Months:Warm (July-November), Cold (December-June)

***** Including also those weighing $38 \mathrm{~kg}$

Attending to the fishing activity which have been obtained, sport fishing or commercial fishing, it can be seen that the largest number of samples came from commercial fishing $(96,3 \%, n=685)$, of which $9,1 \%(n=62)$ were positive. Only $3,5 \%(n=25)$ of samples belongs to sport fishing, but $36,0 \%(n=9)$ have the presence of CTXs (Table 1). There are significant differences between the two activities $(p<0.05)$. As it is expected that a shorter lifespan means a shorter time span available for toxin accumulation in fish tissue, it has been assumed that the risk for CFP may increase with the consumption of larger fish. In that sense, the use of morphometric data for preventing the CFP risk may sometimes be useless for high risk species. ${ }^{6}$ As an example, US authorities are using such an approach in Hawaii where the highrisk species Seriola dumerilii cannot be sold above a threshold weight of $9 \mathrm{~kg} .{ }^{31}$ However, even if this study included the analysis of only 13 fish samples, the present results suggested no clear relation between CTX content and size of specimens. Still, Seriola fasciata sample 2 weighed $37 \mathrm{~kg}$ and is 60 times more toxic than Seriola fasciata sample 5 , which weighed $63 \mathrm{~kg}$. This observation is in agreement with other works. ${ }^{32,33}$ who have reported in the Pacific (French Polynesia) no clear relation between CTXs content and the size of fish specimens. The same authors have also reported the presence of CTXs in both herbivorous and carnivorous fish specimens. ${ }^{34}$

Therefore, the range of fish specimens screened for CTXs by the Public Health Authorities may be equally applicable to fish specimens weighing less than $17 \mathrm{~kg}$ as well. ${ }^{35}$ Besides at the moment, the fish selected for CTXs by Public Health Authorities are specimens of fish weighing more than $15 \mathrm{~kg}$, and this limit is right at the moment, since the smaller amberjack ciguatoxin we found in this study is $16 \mathrm{~kg}$. Focussing on the weight of the received samples, only amberjack species ( $S$. dumerilli and $S$. rivoliana), most of the samples had a weight less than $35 \mathrm{~kg}(86 \%, \mathrm{n}=471)$, of which $10 \%(\mathrm{n}=46)$ were positive. However more samples $(21 \%, n=16)$ with the presence of CTXs were found, in the fish over $35 \mathrm{~kg}(\mathrm{n}=77)$ (Table 1). The variable weight gave significant differences $(p<0.05)$. In this studio, it can be observed that an amberjack weighting $35 \mathrm{~kg}$ or more is a risk factor with almost two times more likely of having ciguatera. So that, it can be recommended the throwing overboard of amberjack of $35 \mathrm{~kg}$ or more if they are alive, and if the fish is dead they should do a check for telltale the toxin.
Table 1 is a multivariable logistic regression for predictors of the risk of having ciguatera among fish proves that the strongest risk factors are the fishing activity which have been obtained (OR 6.68 and $p$ value 0.000 ) and the whole amberjack and grouper off the other species (fish 2 species) (OR 8.21 and $p$ value 0.042). There is other risk factor, the area where the amberjacks were caught in the Canary Islands (OR 1.95 and $p$ value 0.016).Goodness of fit test performed on the multivariable logistic regression model indicated that the model was a good fit (Pearson X2 $=3,055, p=0.383$ ). Multivariable logistic regression analysis revealed a significant association between the area, the fishing activity which have been obtained, the whole amberjack and grouper off the other species and the presence of ciguatoxin in fish. The Eastern area is high risk for ciguatera, while the remaining islands are low-risk area.The commercial fishing activity is high risk for ciguatera, but may be because we receive more samples of this activity than sport fishing.

More samples have been sent to us in the cold months (November to April), $51 \%(\mathrm{n}=368)$, and there were more positives detected $(11 \%$, $\mathrm{n}=41)$ than in warm months (May to October), $9 \%(\mathrm{n}=30)$ (Table 1). There are not significant differences $(P<0.05)$ in the univariate analysis, but we have to keep in mind that other property of the canarian waters temperature is the limited range of winter-summer variation, compared with other temperate and subtropical zones next, ranging normally between $17.5^{\circ}$ and $25{ }^{\circ} \mathrm{C} . .^{29} \mathrm{~A}$ study of the data available for the Canary Islands shows a phase of steady increase in recent decades (mean $21.11^{\circ}$ ), after a previous period colder (in the seventies, the average was $20.33{ }^{\circ} \mathrm{C}$ ), with the maximum value in $1997\left(21.66^{\circ} \mathrm{C}\right)$ and also a number of very warm years later in 2003 and 2004. The trend is clear an increase, although the process is not uniform and there are certain years alternating cold and warm and sporadic phenomena of intense summer heat, as occurred in 2004, when there were more cans surface temperatures known on the islands, reaching the $27^{\circ}-28^{\circ} \mathrm{C}$; during a long period of July-August withdrew the trade winds and warm African air entered dusty (haze), upwelling African decreased significantly and heated water, so that we reached the thermal front. ${ }^{29}$

The coincidence of hot water and the entry of trace elements for phytoplankton production constraints provided by haze, favored the appearance of dinoflagellates. ${ }^{29}$ The invasion of dinoflagellates into 
temperate waters could be a signal of warming in these waters. ${ }^{18}$ The presence of the dinoflagellate Gambierdiscussp. in the Canary Islands was documented in $2004^{22}$ and confirmed in 2011. ${ }^{14}$ This coincides with the detection of the first outbreaks in Canary Islands in 2004 and from 2009 is beginning to make a plan for detecting ciguatoxin in the archipelago, beginning itself to detect fish (amberjacks) carriers of the toxin. ${ }^{34}$ We present in this work the fish analyzed from September 2011 to December 2014, supporting the existence of fish with toxin yet.

Canarian marine biodiversity has certainly affected by climate change. The temperature increase has had a clear influence on the biota, mainly: a) the emergence of new thermophilic species, b) the population growth of native species of tropical origin, as in the case of the wahoo, a pelagic species migration pantropical distribution, which was reproduced for the first time in our waters in 1997 and subsequently experiment expansion into the eastern islands, c) the depletion in the western islands of native species of temperate origin demanding. ${ }^{29}$

The expansion of species with warm seawater affinities has been used as evidence of biological responses to global warming, because the rise of temperature breaks the biogeographical barriers that prevent the arrival and proliferation of species in regions where they were previously absent. The arrival and expansion of non-native species or the increase of native ones can alter species interactions and cause drastic variations in assemblage diversity. ${ }^{30}$ A dusky grouper over 20 $\mathrm{kg}$ that had been poisoning a family that was caught off the coast of Tenerife, was referred to our laboratory by Public Health Authorities. Our analysis identified the toxin in fish and with this we have to recommend that the test limit set by the authorities in the grouper, which is currently $29 \mathrm{~kg}$ should be lowered to $20 \mathrm{~kg}$. Besides all this, there are articles related algae increased, like Gambierdiscus, with rises in sea-surface temperature, and tropical storms frequency and may explain, also, increased incidence of ciguatera in non-endemic areas. ${ }^{15,36-38}$

In conclusion, these results indicate that the island where fishing, the Eastern of Canary Islands, the activity type fishing (commercial), if the captured fish is grouper or amberjack and fish size $(35 \mathrm{~kg}$ if amberjack) are high-risk probability of catching a fish with the ciguatoxin.

\section{Acknowledgments}

None.

\section{Conflicts of interest}

None.

\section{References}

1. Darius HT, Drescher O, Ponton D, et al. Use of folk tests to detect ciguateric fish: a scientific evaluation of their effectiveness in Raivavae Island (Australes, French Polynesia). Food Addit Contam Part A Chem Anal Control Expo Risk Assess. 2013;30(3):550-566.

2. Mak YL, Wu JJ, Chan WH, et al. Simultaneous quantification of Pacific ciguatoxins in fish blood using liquid chromatography-tandem mass spectrometry. Anal Bioanal Chem. 2013;405(10):3331-3340.

3. Murata M, Legrand AM, Ishibashi Y, et al. Structures and configurations of ciguatoxin from the moray eel Gymnothorax javanicus and its likely precursor from the dinoflagelatte Gambierdiscus toxicus. J Am Chem Soc. 1990;112(11):4380-4386.
4. Derne B, Fearnley E, Goater S, et al. Ciguatera fish poisoning and environmental change: a case for strengthening health surveillance in the Pacifier. Pac Health Dialog. 2010;16(2):99-108.

5. Lewis RJ. Detection of toxins associated with ciguatera fish poisoning. Manual on harmful marine algae. In: Hallegreaff et al. (Eds.), UNESCO Publishing, France. 2003;pp.267-277.

6. Caillaud A, de la Iglesia P, Darius HT, et al. Update on the methodologies available for ciguatoxin determination: perspectives to confront the onset of ciguatera fish poisoning in Europe. Mar. 2010;Drug8(6):1838-1907.

7. Friedman MA, Fleming LE, Fernandez M, et al. Cogiatera fish poisoning: treatment, prevention and management. Mar Drugs. 2008;6(3):456-479.

8. Hamilton B, Hurbungs M, Jones A, et al. Multiple ciguatoxins present in Indian Ocean reef fish. Toxicon. 2002;40(9):1347-1353.

9. Bellassoued K, Hamza A, van Pelt J, et al. Seasonal variation of Sarpa salpa fish toxicity, as related to phytoplankton consumption, accumulation of heavy metals, lipids peroxidation level in fish tissues and toxicity upon mice. Environ Monit Assess. 2013;185(2):1137-1150.

10. Schlaich C, Hagelstein JG, Burchard GD, et al. Outbreak of Ciguatera Fish Poisoning on a Cargo Ship in the Port of Hamburg. Journal of Travel Medicine. 2012;19(4):238-242.

11. Mattei C, Vetter I, Eisenblätter A, et al. Ciguatera fish poisoning: A first epidemic in Germany highlights an inchreasinf risk for European countries. Toxicon. 2014;91:76-83.

12. Ledreux A, Ramsdell JS. Bioavailability and intravenous toxicokinetic parameters for Pacific ciguatoxin P-CTX-1 in rats. 2013. Toxicon64:81-86.

13. Lehane L, Lewis RJ. Ciguatera: recent advances but the risk remains. Int J Food Microbiol. 2000;61(2-3):91-125.

14. Fraga S, Rodríguez F, Caillaud A, et al. Gambierdiscus excentricus sp. nov. (Dinophyceae), a benthic toxic dinoflagellate from the Canary Islands (NE Atlantic Ocean). Harmful Algae. 2011;11:10-22.

15. Dickey RW, Plakas SM. Ciguatera: a public health perspective. Toxicon. 2010;56:123-136.

16. García SM, Rosenberg AA. Food security and marine capture fisheries: characteristics trends, drivers and future perspectives. Philos Trans Sci. 2010;365(1554):2869-2880.

17. Boada LD, Zumbado M, Luzardo OP, et al. Ciguatera fish poisoning on the West Africa Coast: an emerging risk in the Canary Islands (Spain). Toxicon. 2010;56(8):1516-1519.

18. Jeong HJ, Lim AS, Jang $\mathrm{SH}$, et al. First report of the epiphytic dinoflagellate Gambierdiscus caribaeus in the temperate waters off Jeju Island, Korea: morphology and molecular characterization. Eukaryotic microbiology. 2012;59(6):637-650.

19. Epelboin L, Pérignon A, Hossen V, et al. Two clusters of ciguatera fish poisoning in Paris, France, related to tropical fish imported from the French Caribbean by travelers. J Travel Med. 2014;21(6):397-402.

20. Fraga S, Riobó $P$, Diogène $J$, et al. Toxic and potentially toxic benthic dinoflagellates observed in Macaronesia (NE Atlantic Archipelago). 11th International Conference on Harmful Algae, Capetown, South Africa. 2004;pp.115.

21. Pérez-Arellano JL, Luzardo OP, Pérez Brito A, et al. Ciguatera fish poisoning, Canary Islands. Emerg Infect Dis. 2005;11:1981-1982.

22. Aligizaki K, Nikolaidis G, Fraga S. Harmful Algae News. Int Ocean Comm UNESCO. 2008;36:6-7.

23. Gouveia N, Delgado J, Gouveia N, et al. Primeiro registo da ocorrência de episoódios do tipo ciguatérico no arquipélago da Madeira. Fitoplancton Toxico e Biotoxinas X Reuniao Oberica. In: Costa et al. (Eds.), IPIMAR, Lisbon, Portugal. 2009;pp.152-157. 
24. Otero P, Pérez S, Alfonso A, et al. First toxin profile of ciguateric fish in Madeira Archipelago (Europe). Analyt Chem. 2010;82(14):6032-6039.

25. Nunez D, Matute P, Garcia A, et al. Outbreak of ciguatera food poisoning by consumption of amberjack (Seriola spp.) in the Canary Islands, May 2012. Euro Surveill. 2012;17(23):pii=20188.

26. Fraga S, Rodríguez F. Genus Gambierdiscus in the Canary Islands (NE Atlantic Ocean) with description of Gambierdiscus silvae sp. nov., a new potentially toxic epiphytic benthic dinoflagelatte. Protist. 2014;165(6):839-853

27. Cañete E, Diogéne J. Comparative study of the use of neuroblastoma cells (neuro-2a) and neuroblastoma x glioma hybrid cells (NG10815) for the toxic effect quantification of marine toxins. Toxicon. 2008;52(4):541-550.

28. Hosmer DW, Lemeshow S. Applied logistic regression. John Wiley \& Sons Inc, New York, USA. 2000.

29. Brito A. Influencia del calentamiento global sobre la biodiversidad marina de las Islas Canarias. Naturaleza amenazada por los cambios en el clima. Actas III Semana Científica Telesforo Bravo. In: AfonsoCarrillo J (Ed.), IEHC, Puerto de la Cruz, Spain. 2009;pp.141-161.

30. Sangil C, Sansón M, Afonso-Carrillo J, et al. Changes in subtidal assemblages in a scenario of warming: proliferations of ephemeral benthic algae in the Canary Islands (eastern Atlantic Ocean). Mar Environ Res. 2012;77:120-128.

31. Cabrera Suárez F, Bilbao Sieyro A, Bermejo Díaz JM, et al. Resultados preliminares en la determinación in situ de la presencia de ciguatera en los puntos de primera venta de pescado en las Islas Canarias. IV Congreso Internacional de Autocontrol y Alimentos Inocuos para Proteger la Salud, Bilbao, Spain. 2010
32. Chinain M, Darius HT, Ung A, et al. Ciguatera risk management in French Polynesia: the case study of Raivavae Island (Australes Archipelago). Toxicon. 2010;56(5):674-690.

33. Darius HT, Ponton D, Revel T, et al. Ciguatera risk assessment in two toxic sites of French Polynesia using the receptor binding assay. Toxicon. 2007;50(5):612-626.

34. Clua E, Brena PF, Lecasble C, et al. Prevalence and proposal for costeffective management of the ciguatera risk in the Noumes fish market, New Caledonia (South Pacific). Toxicon. 2011;58(6-7):591-601.

35. Caillaud A, Eixarch H, de la Iglesia P, et al. Toward the standardisation of the neuroblastoma (neuro-2a) cell-based assay for ciguatoxin-like toxicity detection in fish: application to fish caught in the Canary Islands. Food Additives \& Contaminants: Part A. 2012;29(6):1000-1010.

36. Gingold DB, Strickland MJ, Hess JJ. Ciguatera fish poisoning and climate change: analysis of National Poson Center data in the United States, 2001-2011. Environ Health Perspect. 2014;122(6):580-586.

37. Barrett JR. Under the weather with ciguatera fish poisoning. Environ Health Perspect. 2014;122(6):167.

38. Llewellyn LE. Revisiting the association between sea surface temperature and the epidemiology of fish poisoning in the South Pacific: reassessing the link between ciguatera and climate change. Toxicon. 2010;56(5):691-697. 